\title{
Embedding arts and humanities in the creative economy: the role of graduates in the UK
}

Article

Accepted Version

Comunian, R., Faggian, A. and Jewell, S. (2014) Embedding arts and humanities in the creative economy: the role of graduates in the UK. Environment and Planning C:

Government and Policy, 32 (3). pp. 426-450. ISSN 1472-3425 doi: https://doi.org/10.1068/c11153r Available at https://centaur.reading.ac.uk/36160/

It is advisable to refer to the publisher's version if you intend to cite from the work. See Guidance on citing.

To link to this article DOI: http://dx.doi.org/10.1068/c11153r

Publisher: Pion Ltd

Publisher statement: Comunian, R., Faggian, A. and Jewell, S. (2014). The definitive, peer-reviewed and edited version of this article is published in Environment and Planning C: Government and Policy, 32 (3). pp. 426-450. doi: $10.1068 / \mathrm{c} 11153 r$

All outputs in CentAUR are protected by Intellectual Property Rights law, including copyright law. Copyright and IPR is retained by the creators or other copyright holders. Terms and conditions for use of this material are defined in the End User Agreement. 


\section{CentAUR}

Central Archive at the University of Reading

Reading's research outputs online 


\title{
Embedding Arts and Humanities in the Creative
}

\section{Economy: the role of graduates in the UK}

\begin{abstract}
The recent change in funding structure in the UK Higher Education system has fuelled an animated debate about the role that Arts and Humanities (A\&H) subjects play not only within Higher Education but more broadly in the society and the economy. The debate has engaged with a variety of arguments and perspectives, from the intrinsic value of $\mathrm{A} \& \mathrm{H}$, to their contribution to the broader society and their economic impact, particularly in relation to the creative economy, through knowledge exchange activities. The paper argues that in the current debate very little attention has been placed on the role that A\&H graduates play in the economy, through their work after graduation, and specifically in the creative economy. Using Higher Education Statistical Agency (HESA) data we analyse the performance of A\&H graduates (compare to other graduates) and particularly explore how embedded they are with the creative economy and its associated industries. The results highlight a complex intersection of different sub-disciplines of the A\&H with the creative economy but also reveal the salary gap and unstable working conditions experienced by graduates in this field.
\end{abstract}




\section{Introduction ${ }^{\mathrm{i}}$}

The role played by Arts and Humanities (from now on referred to as A\&H) research and knowledge in the UK has been recently questioned in connection with the changes introduced in the funding structure of the Higher Education (HE) system in England. Under the new system (which will be implemented starting from the academic year 2012/13), direct public funding for teaching is to be withdrawn from HE institutions (HEIs) in all subjects but the ones associated with high teaching $\operatorname{costs}^{\mathrm{ii}}$ (such as clinical medicine, health-care and lab-based sciences). For all 'standard' subjects - including A\&H subjects public funding is to be replaced by increasing loan-based income paid by the students themselves when registering for their HE course. In a system such as the new one, where the costs of HE are borne in a larger proportion by individuals rather than society, students are becoming more and more aware of what kind of 'value-for-money' a course provides. Recent research has confirmed the popular belief that social sciences and A\&H subjects are, on average, associated with lower paid jobs and hence they are economically less advantageous than science, technology, engineering, and mathematics (also known as STEM) courses (Finnie and Frenette 2003; Abreu et al. 2011; Comunian, Faggian, and Li 2010). These studies highlight that $A \& H$ graduates receive lower economic rewards from their degrees and that their career patterns are precarious, with less full-time positions available. While these issues have been acknowledged in few research political speeches (Willetts 2011 and Shattock, 2010), the new rhetoric tends to focus instead on the broader role and contribution of A\&H research in promoting societal welfare (Florida 2002; Bullen, Robb, and Kenway 2004; Willetts 2011).

A great deal of attention has also been placed by policy makers and HE policy think-tanks on the role played by universities (and specifically A\&H subjects) in fostering the 'creative economy' in the UK (Universities UK 2010; Million + 2008). As the creative economy is currently being presented as one of the leading success stories of the UK economy (The Work Foundation 2008), linking the A\&H research to this sector has become strategically important for HEIs, to be able to access funding opportunities and partnership with local authorities and external organisations ${ }^{\mathrm{iii}}$ (Comunian, Smith, and 
Taylor forthcoming). HEIs are now sitting on local policy committee, involved in local planning for the creative economy. Similarly, in the academic literature the importance of the 'creative class' (Florida 2002) and the creative industries (Jayne 2005; Fingleton et al. 2007) as a key strategy for local economic development has generated a lively debate (Glaeser 2005; Peck 2005) but has certainly placed universities at even a higher position in the local development agenda.

These different perspectives (from policy to academic research) are useful in helping us framing the debate emerging on the value of $\mathrm{A} \& \mathrm{H}$, which strongly hinges on the balance between three dimensions: A\&H graduates job perspectives, socio-cultural value of $\mathrm{A} \& \mathrm{H}$ research and its potential contribution to the creative economy. While in the broader literature on economic development and human capital, the role and importance of university graduates in the UK has been widely discussed (Mathur 1999; Faggian and McCann 2009, 2006), very little (if no) attention has been specifically placed on A\&H graduates and how their fundamental role for society reconciles with their, supposedly, weaker position in the labour market.

This paper aims to address this gap in the literature, looking specifically at the employment trajectories of $\mathrm{A} \& \mathrm{H}$ graduates and their contribution to the creative economy, compared to non-A \& $\mathrm{H}$ graduates. The paper is organised in four parts. Section 2 presents the complex policy context in which the paper sets and summarises the most important academic contributions on the topic. Section 3 describes the data and methodology used. Section 4 describes our main results on A\&H graduates career patterns and their interconnections with the creative economy. Finally, Section 5 discusses some initial policy implications of our results and provides conclusions. 


\section{Literature and policy context}

In order to understand the scope of this paper, it is important to map and articulate the multidisciplinary research landscape that surrounds it and hinges around three interconnected topics:

- the concept creative economy and its links with the creative industries and creative class theory;

- the role and importance of HEIs in producing human capital and hence fostering local and national development;

- the role of $\mathrm{A} \& \mathrm{H}$ knowledge - especially the one embodied in A\&H graduates - in helping a society to thrive.

\subsection{Creative economy, creative industries and the creative class}

The concept of the 'creative economy' underwent an important policy and theoretical evolution in recent years ${ }^{\text {iv }}$. Traditionally in the UK the concept has been linked to that of 'creative industries' as defined by the Department for Culture, Media and Sport (DCMS, 1998): “...industries which have their origin in individual creativity, skill and talent which have a potential for job and wealth creation through the generation and exploitation of intellectual property". The creative industries have been high on the policy agenda in the UK since the New Labour came to power in 1997 and they have been the subject of numerous policy initiatives ever since (DCMS 1999, 2003; DCMS and BERR 2008) including the growing attention of the current Government to this area of research (The Economist 2010). The DCMS (1998) definition and policies refer specifically to creative 'industries', i.e. businesses and activities identified as creative $\mathrm{e}^{\mathrm{v}}$. There is no specific reference to workers and human capital employed in the sector.

The strong attention towards the creative industries as a sector was initially due to its strong (although sometimes questionable see Taylor 2006) - economic performance: growing at twice the rate of the rest 
of the economy (The Work Foundation 2008). In 2008, the sector accounted for $5.6 \%$ of the Gross Value Added (GVA) of the UK economy and 7.8\% of all employment in UK (DCMS 2010a) ${ }^{\text {vi }}$.

The initial DCMS definition of creative industries has evolved over time. In particular, there has been a shift of attention from an approach based on industrial composition towards a broader understanding of creative activities, which encompasses also creative activities outside the traditional defined 'creative industries'. More emphasis was also put on the creative workforce (Baines and Robson 2001) and creative supply-chain (Pratt 1997) which support the creative production process.

Part of the reason for this shift is attributable to the success of the concept of 'creative class', popularised by Florida in 2002. The work of Florida highlighted the importance of the 'creative class' and 'creativity' as a 'driving force in regional economic growth and prosperity' (Florida 2002, 2002, 2002; Stolarick and Florida 2006). In Florida's own words at the core of the creative class there are 'people in science and engineering, architecture and design, education, arts, music and entertainment, whose economic function is to create new ideas, new technology, and/or new creative content', but also 'the creative professionals in business and finance, law, healthcare and related fields. These people engage in complex problem solving that involves a great deal of independent judgment and requires high levels of education or human capital' (Florida 2002, , p.8). This definition encompasses a much larger group of professionals than the ones identified by the creative industries DCMS approach and it puts more attention towards individual 'creative' workers and practitioners and their socio-economic role in specific local and urban areas.

Despite the many criticisms that the concept of creative class received (Montgomery, 2005, Comunian, 2009, 2011 and Peck, 2005) and the recognition that the concepts of creative industries and creative class are somehow 'disconnected' (Comunian et al., 2010), the work initiated by Florida had the undisputed ability to raise awareness on the role of 'creativity' in society and spurred a whole series of contributions (academic and non-academic) on the topic ${ }^{\mathrm{vii}}$. 
Among these contributions, a growing area of research is engaging with a better definition of the creative industries, which does not stop at the industrial classification, but rather explores links to value-chain approaches and the range of occupational opportunities in this field (NESTA 2008; Frontier Economics 2009).

Consistent with the theoretical framework described in previous contributions (e.g., Comunian et al. 2010), this paper uses the term 'creative economy' as defined by the NESTA 2008 report (NESTA, 2008). While more details are provided in the methodology section, we adopted this definition to acknowledge that, while the activities (and jobs) within the creative industries are at the core of research on the creative economy, the work of creative practitioners and professionals outside the traditionally defined creative industries is also of paramount importance. This is particularly true when trying to map the interconnection not only between $\mathrm{A} \& \mathrm{H}$ and the creative industries, but also with creative occupations outside the traditional definition of creative industries.

\subsection{HEIs and human capital}

Strictly related to the 'creative economy' are the concept of human capital and the role of HEIs. The literature on the subject is very extensive and a thorough review is therefore beyond the scope of this paper $^{\text {viii }}$, but some key connections with the creative economy need to be underlined.

Firstly, the human capital concept is not dissimilar from the concept of 'talent' which has been used extensively in the creative class literature (Mellander and Florida 2007) and HEIs play a vital role in producing it via the provision of graduates. A highly educated workforce (Florida 1999) is key to economic success and graduates, although very mobile (Faggian et al. 2007), can strongly influence the local economic development of specific contexts. Etzkowitz and Leydesdorff (2000) and Faggian and McCann (2006) argue that the supply of graduates may in fact be universities most important contribution to innovation, which goes well beyond the impact of knowledge spillovers, the formation of spin-off companies and knowledge transfer. 
However, many argue that the role of knowledge spillovers, spin-offs, and knowledge transfer in general, should not be underestimated as they enrich the regional context, foster innovation (Audretsch, Lehmann, and Warning 2005; Huggins and Johnston 2009) and economic benefits follow (Anselin, Varga, and Acs 2000). Different HEIs have different approaches (more or less entrepreneurial) in managing these spillovers (Clark 1998) also linked to the kind of infrastructures they are provided with, such as a new incubator space (Rothaermel and Thursby 2005) or new premises and conference facilities as well as new networking spaces or virtual platforms for interaction.

\subsection{A\&H graduates: a cross road between creativity and human capital?}

Within the broader literature on creativity, human capital and the role of HEIs, a range of contributions started focusing on the role played by $\mathrm{A} \& \mathrm{H}$, both its research and teaching, on the welfare of society and how to measure it. In fact, as reported by Benneworth and Jongbloed (2000), from 2005/2006 an increase emphasis was placed on impact by the Arts \& Humanities Research Council (AHRC) - the leading funding body for A\&H in the UK - to demonstrate the role of its activities and create specific funding programmes to support knowledge transfer.

The concept of knowledge transfer (usually labelled knowledge exchange or external engagement in the A\&H context) has become increasingly important in making the argument that $\mathrm{A} \& \mathrm{H}$ have a positive impact on society and provide good value for money. Some authors have seen this new pressure for knowledge transfer/exchange as an imposition of a 'techno-economic' paradigm to A\&H (Bullen, Robb, and Kenway 2004) but most HEIs have married this new perspective thinking of it as an opportunity to add value to their work (Powell 2007; Lindberg 2008). The knowledge connections which A\&H develop with the creative economy are considered particularly important as measures of impact and engagement (Comunian, Smith, and Taylor forthcoming) and, although the evidence gather is mostly anecdotal, there is an increasing pressure - felt also by the AHRC - to show the importance of these dynamics (Hughes et al. 2011; Bakhshi, Schneider, and Walker 2008). In this urge to gather case 
studies and evidences in support of the role of the A\&H on societal welfare, universities associations and think-tanks have also contributed to the debate (Million + 2008; Universities UK 2010).

It seems that in the current climate HEIs are expected to function as a kind of R\&D laboratories (Cunningham et al. 2004) and be part of the broader innovation system (Bakhshi, Schneider, and Walker 2008), and that this applies to all subjects, not just STEM. It is easy to recognise how much the HEIs landscape has changed in the last seven years, since Cunningham et al. suggested that 'the creative industries appear to be marginal within university-based research' (Cunningham et al. 2004, , 176) or when the Lambert Review (HM Treasury 2003) pointed out that "there are many excellent examples of collaborations involving the creative industries and universities or colleges of art and design. Policy-makers must ensure that policies aimed at promoting knowledge transfer are broad enough to allow initiatives such as these to grow and flourish, and that the focus is not entirely on science and engineering" (HM Treasury, 2003:45).

While the emphasis in proving the impact of $\mathrm{A} \& \mathrm{H}$ on society has recently focused mainly on knowledge transfer, there is, however, another dimension of the impact of A\&H which has been disregarded, i.e. the production of A\&H graduates. While the impact of graduates in general has been discussed elsewhere (Chatterton 1999; Comunian and Faggian 2011; Cross and Pickering 2008; Cantor 2005), no study has focused on A\&H graduates, with studies focussing on narrower versions of ‘creative' graduates (Abreu et al., 2011; Comunian et al., 2010). As Faggian and McCann (2006, 2009) argue, the primary role of the university system is being a conduit for bringing potential high quality undergraduate human capital into a region and having a highly skilled labour pool far outweighs the benefits generated by knowledge spillovers. Hence, attracting and retaining higher human capital and creative individuals is a more effective long-term strategy for local economic development (Mathur 1999; Florida 1999).

Despite focusing on knowledge exchange and engagement, most of the recent policy initiatives also seem to have highlighted the importance of graduates (especially in relation to employability and skills) 
and their connection to the creative economy. In fact, as most of the case studies presented by Universities UK (2010) and Million + (2008) highlights, many of the knowledge connections experienced by academics are also linked to their teaching activities or involve students and graduates. It can be argued that an assessment of the relevance and interconnection of $\mathrm{A} \& \mathrm{H}$ with the creative economy (and the broader economy) cannot abstain from looking at the role of A\&H graduates, as they represent the main conduit for $\mathrm{A} \& \mathrm{H}$ knowledge to reach into our economy and society. This key transfer of knowledge is sometimes overlooked in favour of 'research/practise-led' knowledge being exchanged or developed directly through collaboration.

Many A\&H graduates are involved in new start-up activities strongly embedded in the local business community and sometimes provide also support for teaching. Brown (2007), in his survey of performing arts departments, found that these departments are 'extensively working with professional communities of practice as major element of their teaching' (p.47). Graduates are not only a conduit of knowledge from HEIs to society; they are also a conduit of specific knowledge from industry to academia. In this sense they are able to foster local networks and 'people-based environment' (Crossick 2009) which are essential for knowledge transfer, particularly in the A\&H field. Araya (2010) highlights the importance of embedded communities of practice and networks which connect the education with the creative economy.

The employability and ability of A\&H graduates to access the creative economy labour market is one of the pillars of knowledge exchange. However, some recent contributions have highlighted the difficulties faced by 'creative or bohemian graduates' ${ }^{\text {ix }}$ (see Comunian et al. 2010, Faggian et al., forthcoming ) in finding suitable graduate jobs and entering their field of study Pitcher and Purcell (1998) explore the expectation of graduates in $\mathrm{HE}$ and suggest that students in $\mathrm{A} \& \mathrm{H}$ (as well as Languages and Social sciences) have less of an idea about were their HE course might lead them and about their future career development. Brown and Hesketh (2004) have argued that the 'knowledge economy' has not expanded so rapidly as to accommodate all the highly skilled graduates leaving university. This argument in the 
A\&H areas meets with further concerns about the oversupply of artists in general (Towse 2001; Abbing 2002). However, no previous study has specifically looked in quantitative terms at overall picture of at the relationship between $\mathrm{A} \& \mathrm{H}$ graduates and the creative economy.

\section{Research objectives, data and methodology}

\subsection{Research objectives}

There is a gap in the literature in the understanding of the contribution and value of A\&H graduates in the labour market and more specifically in the creative economy. Although there are many ways to address this gap - and we acknowledge that it is difficult to exactly define what 'value' means (and how it can be measured) - the paper offers a first exploration of these topics issues using the available quantitative data on career patterns of A\&H. Even though, ideally, our analysis will be integrated in the future with more qualitative work, it was important first to identify some key trends and to model the patterns and dynamics of $\mathrm{A} \& \mathrm{H}$ graduates (as a whole and divided into sub-disciplines) careers to build upon with future research. In particular, using the UK Higher Education Statistical Agency (HESA) data (with their strengths and limitations), , the paper aims to address the following objectives:

- Profile and analyse the performance of $\mathrm{A} \& \mathrm{H}$ graduates compared to other graduates. In order to do that, we use key labour market indicators such as employment status, type of employment and salary, and highlight differences and specificities both within the A\&H graduate group and of the whole group compared to other graduates.

- Understand how 'embedded' A\&H graduates are in the creative economy (i.e. both in creative industries and creative occupations). The integration of $\mathrm{A} \& \mathrm{H}$ graduates in the creative economy is captured using the sector of employment (based on SIC codes) and type of occupation (based on SOC codes) in line with NESTA (2008). Although we do not capture other valuable forms of 
exchange and interaction - such as informal networking - ours is an important step towards recognising how much $\mathrm{A} \& \mathrm{H}$ graduates contribute to the creative economy and in which capacity.

- Finally, we look at the effect that the creative economy has on A\&H graduates careers by looking at the salary and job levels (graduates vs. non-graduate job) of A\&H when employed in the creative industries and occupations vis-à-vis being employed elsewhere.

\subsection{HESA Data}

Our analysis is based on data from the 'Students in Higher Education' and the 'Destinations of Leaves from Higher Education' (DLHE) survey, both collected by the UK Higher Education Statistical Agency (HESA). The former contains data on all students (both postgraduate and undergraduate level) enrolled in UK HEIs, while the latter, generally targeted towards British domiciled students, is a survey undertaken every year, by each institution on behalf of HESA, to collect information about graduates' employment activities six months after graduation. HESA has a target response rate of $80 \%$ for full time home domiciled graduates, $70 \%$ for part time home domiciled graduates and $50 \%$ for EU graduates. Given the lower response rates of non-British domiciled students, we only analyse British domiciled students (both part time and full time) and, in particular, we focus on the cohort of studentswho graduated in 2005 (with a DLHE return referring to their employment situation in January 2006). Second, in line with the literature on the topic (Comunian et al. 2010 and Abreu et al. 2011) and due to the lower response rate of postgraduates and other undergraduates (those below first degree level) to the DLHE survey, we focus on first degree undergraduates ${ }^{\mathrm{x}}$, who represent $61 \%$ of the full 'Students in Higher Education' sample. As we are interested in employment patterns, these two years are particularly good as they refer to the pre-recession period. The recession which took place following the 2007 credit crunch in UK had a negative effect on graduates' employment in general (Shattock 
2010), but it might have impacted graduates from different disciplines differently hence biasing our results.

The Students in Higher Education data contain individual student record data giving information on a series of variables including: personal characteristics (such as gender, age and ethnicity), subject of study (at the 4 digit Joint Academic Coding System (JACS ${ }^{\mathrm{xi}}$ ) code), mode (full time vs. part time), degree results and institution attended. The DLHE survey, which is matched to the student record data, includes information on the graduate's employment, in particular: salary level, employer sector code (4digit SIC code), job occupational code (4-digit SOC code), location of employment (postcode).

For the 2005 cohort of graduates, the student dataset includes 268,143 records of British domiciled finalists (who are all eligible for a DLHE return), from 164 HEIs. The DLHE data has information on 207,271 British domiciled graduates, which equates to an overall $77 \%$ response rate (table 1). Although the response rate does vary by subject groups, there is no evident over- or under- representation of subjects in the DLHE sample when compared to the finalist sample ${ }^{\mathrm{xii}}$. We will make use of both samples, using the finalists' sample to examine where students study and the DLHE return sample to examine employment patterns.

Our main interest is to study how A\&H students and graduates fare relative to non-A\&H ones. Following the research landscape set up by AHRC (2011) we identify A\&H students using the JACS codes and divide them in the following sub-disciplines:

- Architecture, Building and Planning (all JACS codes beginning with K)

- Mass Communications and Documentation (all JACS codes beginning with P)

- Creative Arts and Design (all JACS codes beginning with W)

- Historical and Philosophical studies (all JACS codes beginning with V)

- $\quad$ Languages (all JACS codes beginning with Q,R,S,T)

- Law (all JACS codes beginning with M). 
Following this classification (table 1), around $32.7 \%$ of undergraduate students belong to A\&H, with the largest category being 'Creative Arts and Design' which comprises $10.32 \%$ of the student population, followed in order by 'Languages' (7.45\%), 'Historical and Philosophical studies' (5.44\%), 'Law' (4.56\%), 'Mass Communications and Documentation' (2.96\%) and finally 'Architecture, Building and Planning' (1.96\%).

Table 1: Finalist and DLHE Sample Composition

\begin{tabular}{|c|c|c|c|c|c|}
\hline Subject groups & $\begin{array}{l}\text { Finalists } \\
\text { (Absolute } \\
\text { numbers) }\end{array}$ & Percentage & $\begin{array}{c}\text { DLHE } \\
\text { Returns } \\
\text { (Absolute } \\
\text { numbers) }\end{array}$ & Percentage & $\begin{array}{r}\text { DLHE } \\
\text { Return } \\
\text { Response } \\
\text { rate }\end{array}$ \\
\hline Non Arts and Humanities & 180,462 & 67.3 & 138,531 & 66.84 & 76.76 \\
\hline Arts and Humanities & 87,681 & 32.7 & 68,740 & 33.16 & 78.40 \\
\hline Architecture Building and Planning & 5,247 & 1.96 & 3,822 & 1.84 & 72.84 \\
\hline $\begin{array}{l}\text { Mass Communications and } \\
\text { Documentation }\end{array}$ & 7,947 & 2.96 & 6,201 & 2.99 & 78.03 \\
\hline Creative Arts and Design & 27,685 & 10.32 & 21,656 & 10.45 & 78.22 \\
\hline Historical and Philosophical studies & 14,582 & 5.44 & 11,505 & 5.55 & 78.90 \\
\hline Languages & 19,990 & 7.45 & 16,019 & 7.73 & 80.14 \\
\hline Law & 12,230 & 4.56 & 9,537 & 4.6 & 77.98 \\
\hline Total & 268,143 & 100 & 207,271 & 100 & 77.30 \\
\hline
\end{tabular}

\subsection{Methodology}

Using a creative job approach à la Cunningham et al (2004) we consider both creative careers within the creative industries but also creative occupations in other non-creative industries. Our definition of a creative job is based on the initial DCMS definition based on 4-digit SIC codes. However, we supplement this definition with the inclusion of other creative workers (based on occupations using 4digit SOC codes that are defined as creative) based in industries outside the creative industries ${ }^{\text {xiii }}$ as identified by DCMS (2010b) (see also Comunian et al. 2010 for detailed SOC and SIC codes). Moreover, we also took on board some of the criticisms to the DCMS definition provided by a recent report by NESTA $(2008)^{x i v}$. 
Following NESTA (2008), we also classify a creative job as being one of the following:

- Specialised - in a creative occupation within the creative industries;

- Supported - in a non-creative occupation within the creative industries;

- Embedded - in a creative occupation outside the creative industries.

When breaking down creative jobs into finer creative sector categories, we use the following groups: Advertising, Architecture and design engineers, Design, Designer fashion \& crafts, Film, TV, Radio and Photography, Music and Visual Performing Arts, Publishing, Software, computer games \& Electronic Publishing, Libraries, museums and cultural activities ${ }^{\mathrm{xv}}$. Having sub-groups is important as creative jobs are very heterogeneous and there are substantial differences between sub-groups (Cunningham and Jaaniste 2010) and different subjects may be more closely linked to different creative sectors.

We begin by drawing a profile of A \& $\mathrm{H}$ students compared to non $\mathrm{A} \& \mathrm{H}$ students with the use of basic descriptive statistics. We then move on to looking specifically at how A \& H students are utilised in the creative economy and which sectors and regions they enter. In particular, we are interested in the role of A \& H graduates in the labour market and the type of job they find. We classify the job 'type' into three categories: specialised, supportive and embedded (as defined above). We model creative job type using a multinomial logit model (MNL)-with robust standard errors to control for heteroskedasticity- where the categorical dependent variable is 'creative job type' and takes four values: non-creative, specialised, supportive and embedded.

The multinomial model is set up as follows:

$\ln \left(\frac{P_{J}}{P_{B}}\right)=\beta_{J / B} X+\varepsilon$ 
$\mathrm{P}_{\mathrm{J}}$ refers to the probability of being in category $\mathrm{J}$ and $\mathrm{P}_{\mathrm{B}}$ the probability of being in the base category (in our case non-creative employment). $\mathrm{X}$ is our set of explanatory variables and $\varepsilon$ is a random error term. The coefficient for each explanatory variable is to be interpreted relative to the base category. To make the beta coefficients more intuitive we calculate the relative risk ratio (RRR), as follows:

$$
\left(\frac{\mathrm{P}_{\mathrm{J}}}{\mathrm{P}_{\mathrm{B}}}\right)=\exp \left(\beta_{J}-\beta_{B}\right) X
$$

A RRR below 1 indicates that a variable negatively affects the probability of being in category $\mathbf{J}$ relative to the base category, and likewise a value above 1 indicates the variable positively affects this probability. We include as explanatory variables in our MNL model: gender, age, ethnicity, disability status, institution type, degree classification, subject group and region of study (all dummy variables).

One criticism of the MNL framework is that it relies on the independence of irrelevant alternatives (IIA) axiom. The IIA axiom states the ratio of the probability of two choices should not be altered by the inclusion of another alternative i.e. choices are independent of each other (for more on the IIA axiom see Train, 2003). Therefore it is important for a multinomial logit model to pass the IIA axiom, which can be tested by means of a Hausman test (Hausman and McFadden, 1984) or a Small-Hsiao test. In our models the Hausman and Small-Hsiao tests provides no evidence that the IIA axiom is violated.

Finally we are interested in comparing the salary differences between $\mathrm{A} \& \mathrm{H}$ students and non $\mathrm{A} \& \mathrm{H}$ students, as well as how salary is affected by being in a creative job and the creative job type and sector. We therefore make use of Mincer-type earning equations . Formally a Mincer wage equation takes the form:

$\ln W=\beta X+\varepsilon$ 
Where the dependent variable is the natural logarithm of earnings (W), $\mathrm{X}$ is a vector of explanatory variables and $\varepsilon$ is a random error term. We include the same explanatory variables as in the MNL models plus job characteristics: type of creative job, sector of creative job their work mode (part time, self-employed/freelance vs. full time employment) and region of employment instead of region of study.

Salary (with the full time equivalent asked for those working less than full time) is reported by 69,272 employed individuals and we exclude those who claim to earn less than the national minimum wage $\mathrm{xvi}^{\mathrm{vi}}$ and following Chevalier (2011) exclude those who earn more $£ 60,000$ or more, leaving 67,241 useable salary observations.

\section{Results}

\subsection{Arts and Humanities graduates: a profile}

Before discussing the interconnections between $\mathrm{A} \& \mathrm{H}$ graduates and the creative economy, it is important to draft a profile of A\&H graduates in the UK. In this section we will focus specifically on three aspects: their geographical distribution across the different British HEIs; the types of HEIs attended and their employment patterns after graduation.

As far as geographical distribution of A\&H students was concerned, the largest proportion of them was located, as expected, in South East and London with the North West coming in third. However, a breakdown by A\&H sub-groups reveals some interesting patterns of regional specialization (Table 2a). For example, 'Architecture, Building and Planning' (ARCH), 'Mass Communications and Documentations' (COMM), 'Creative Arts and Design' (CREA) and 'Law' (LAW) had a greater presence in London than 'Historical and Philosophical studies' (HIST) and 'Languages'(LANG). Scotland seemed specialised in 'Architecture, Building and Planning', while the East Midlands had a high proportion of students in 'Mass Communications and Documentation'. 
Table 2: Students in each subject by region of study and HEI type (absolute numbers and \%)

\begin{tabular}{|c|c|c|c|c|c|c|c|c|c|c|}
\hline & $\begin{array}{c}\text { Total } \\
\text { Students }\end{array}$ & $\begin{array}{c}\text { \% of } \\
\text { Total } \\
\text { students }\end{array}$ & $\begin{array}{c}\text { NON } \\
\text { AH } \\
(\%)\end{array}$ & $\begin{array}{l}\text { AH } \\
(\%)\end{array}$ & & & & & & \\
\hline Region & & & & & $\begin{array}{c}\mathbf{A R C H} \\
(\%)\end{array}$ & $\underset{(\%)}{\operatorname{COMM}}$ & $\begin{array}{c}\text { CREA } \\
(\%)\end{array}$ & $\begin{array}{c}\text { HIST } \\
(\%)\end{array}$ & $\begin{array}{l}\text { LANG } \\
(\%)\end{array}$ & $\begin{array}{c}\text { LAW } \\
(\%)\end{array}$ \\
\hline South East & 38,055 & 14.19 & 13.78 & 15.05 & 7.97 & 12.61 & 14.9 & 20.17 & 15.76 & 12.74 \\
\hline Greater London & 36,215 & 13.51 & 13.08 & 14.39 & 13.72 & 17.1 & 19.48 & 8.28 & 10.77 & 14.58 \\
\hline North West & 29,482 & 10.99 & 10.81 & 11.38 & 11.36 & 10.33 & 11.05 & 12.24 & 13.02 & 9.1 \\
\hline $\begin{array}{l}\text { Yorkshire and The } \\
\text { Humber }\end{array}$ & 26,362 & 9.83 & 9.78 & 9.93 & 11.02 & 10.17 & 7.83 & 11.68 & 11.8 & 8.89 \\
\hline East Midlands & 23,102 & 8.62 & 8.13 & 9.62 & 13.97 & 12.8 & 10.38 & 6.81 & 8.23 & 9.59 \\
\hline South West & 19,789 & 7.38 & 7.18 & 7.78 & 7.51 & 10.52 & 9.26 & 6.47 & 6.64 & 6.21 \\
\hline Scotland & 26,301 & 9.81 & 10.91 & 7.54 & 15.28 & 7.52 & 5.27 & 8.91 & 7.21 & 8.28 \\
\hline West Midlands & 20,871 & 7.78 & 8.25 & 6.83 & 3.39 & 6.4 & 6.75 & 6.1 & 7.66 & 8.27 \\
\hline Wales & 15,550 & 5.8 & 5.48 & 6.46 & 5.03 & 5.4 & 6.42 & 6.34 & 6.91 & 7.25 \\
\hline East of England & 12,017 & 4.48 & 4.37 & 4.71 & 3.43 & 0.63 & 4.18 & 5.88 & 5.39 & 6.58 \\
\hline North East & 12,984 & 4.84 & 5.14 & 4.23 & 2.63 & 4.64 & 3.26 & 4.32 & 5.18 & 5.2 \\
\hline Northern Ireland & 7,415 & 2.77 & 3.09 & 2.09 & 4.69 & 1.87 & 1.22 & 2.8 & 1.44 & 3.31 \\
\hline \multicolumn{11}{|l|}{ HEI Type } \\
\hline Russell Group & 63,841 & 23.81 & 24.19 & 23.03 & 22.34 & 7.15 & 6.46 & 40.51 & 36.41 & 28.46 \\
\hline Other 'Old' & 69,893 & 26.07 & 27.01 & 24.13 & 13.42 & 13.51 & 12.27 & 38.61 & 33.42 & 29.99 \\
\hline New & 108,630 & 40.51 & 41.24 & 39.02 & 59.73 & 61.16 & 54.58 & 13.8 & 21.39 & 39.39 \\
\hline Colleges & 25,779 & 9.61 & 7.57 & 13.83 & 4.52 & 18.18 & 26.69 & 7.08 & 8.79 & 2.16 \\
\hline Total & 268,143 & 100 & 100 & 100 & 100 & 100 & 100 & 100 & 100 & 100 \\
\hline
\end{tabular}


This geographical distribution was also partially explained by the type of HEIs present in each region, as different types of HEIs specialise in the provision of courses in different areas (Table 2b). Comunian and Faggian (2011) specifically look at the overlap between the geography of HEIs provision in creative subjects and HEIs institutional type. They specifically discuss the concentration of courses and specialised institutions $^{\text {xvii }}$ in Greater London and the South East and their implications. The same geographical concentration was identified by previous research also on the distribution of the creative industries in UK (NESTA, 2009). However, as Jayne (2005) highlights, the hype of regional development discourses for the support of creative policies in UK regions has tried to contrast the London-centric distribution of the sector.

Overall, from Table $2 \mathrm{~b}$ we can see that while Russell group ${ }^{\mathrm{xviii}}$ and other 'old' HEIs have traditionally focused on subjects such as 'Languages', 'History and Philosophy', 'new' universities cater for more than half the students in creative and communication courses and $60 \%$ of students in 'Architecture, Building and Planning'. We will return to the role played by different institutional type when looking at the salary of A\&H graduates because - as Comunian et al. 2010 point out - the concentration of subject in certain institutional types may have an impact on the labour market outcomes of graduates due to 'signalling'.

It is interesting to compare the different employment patterns experienced by A\&H graduates and nonA\&H graduates. Indeed, by looking at Table 3, it is clear that non-A\&H graduates are more likely to be in full-time employment or to combine work with further study. A\&H graduates, on the other hand, are more likely to be working part-time, be in a voluntary or unpaid work, be in further study full-time or be unemployed. Unemployment is particular severe among creative arts graduates. Among the A\&H subjects, ‘Architecture, Building and Planning', and 'Mass Communications and Documentation' does particularly well with a proportion of graduates in full-time employment even higher than non-A\&H graduates (62.90\%/58.70 vs. $55.74 \%)$. 
Table 3: Type of employment by subject studied

\begin{tabular}{|c|c|c|c|c|c|c|c|c|}
\hline Destination & $\begin{array}{c}\% \\
\text { NON } \\
\text { AH }\end{array}$ & $\% \mathbf{A H}$ & $\begin{array}{c}\% \\
\text { ARCH }\end{array}$ & $\begin{array}{c}\% \\
\text { COMM }\end{array}$ & $\begin{array}{c}\% \\
\text { CREA }\end{array}$ & $\begin{array}{c}\% \\
\text { HIST }\end{array}$ & $\begin{array}{c}\% \\
\text { LANG }\end{array}$ & $\begin{array}{c}\% \\
\text { LAW }\end{array}$ \\
\hline Full-time paid work & 55.74 & 44.61 & 62.90 & 58.70 & 42.70 & 41.86 & 47.79 & 30.45 \\
\hline Part-time paid work & 7.57 & 8.81 & 2.46 & 10.10 & 12.29 & 8.23 & 7.95 & 4.78 \\
\hline Voluntary/Unpaid work & 0.71 & 1.18 & 0.31 & 1.06 & 1.22 & 1.64 & 1.34 & 0.71 \\
\hline Work and Study & 8.90 & 7.77 & 13.95 & 4.73 & 6.49 & 8.24 & 7.20 & 10.60 \\
\hline Further Study only & 11.89 & 18.04 & 8.82 & 5.71 & 10.18 & 21.30 & 19.87 & 40.56 \\
\hline Assumed to be unemployed & 5.85 & 6.83 & 3.77 & 7.64 & 9.28 & 6.80 & 5.75 & 3.83 \\
\hline $\begin{array}{l}\text { Not available for } \\
\text { employment }\end{array}$ & 4.73 & 5.35 & 3.82 & 5.32 & 4.43 & 7.15 & 5.88 & 5.01 \\
\hline Other & 1.04 & 1.40 & 0.60 & 1.31 & 1.77 & 1.55 & 1.27 & 0.96 \\
\hline Explicit refusal & 2.07 & 2.11 & 1.52 & 2.24 & 2.72 & 1.78 & 1.61 & 2.12 \\
\hline $\begin{array}{l}\text { Self-employed (inc with } \\
\text { study) }\end{array}$ & 1.50 & 3.89 & 1.86 & 3.20 & 8.93 & 1.45 & 1.34 & 0.98 \\
\hline No of obs. & 180,462 & 87,681 & 5,247 & 7,947 & 27,685 & 14,582 & 19,990 & 12,230 \\
\hline Graduate job (\%) & 67.61 & 53.92 & 90.97 & 49.66 & 52.50 & 47.60 & 52.42 & 51.19 \\
\hline
\end{tabular}

Proportion in graduate jobs are for those in employment

A\&H have a higher (more than double) rate of self-employment (which includes self-employment alongside further studying) than non-A\&H graduates, particularly ‘Creative Arts and Design' graduates ( $8.93 \%$ vs. $3.89 \%$ the A\&H group average). Law graduates are the least likely to be in full-time employment, but simply because a very high proportion of them are completing further studies, which are pre-requisite for their future profession. Although this imposes costs in the short term, this extra investment in further studies generally brings high long-term monetary rewards. Graduates from subjects popular at Russell group and other 'old' HEIs, such as 'Historical and Philosophical studies' and 'Languages', are also more likely to be in further study. This might be linked to the fact that these HEIs are generally more research-intensive and hence more likely to be able to offer scholarships for postgraduate studies, and students at these institutions may be of a higher ability.

A\&H and non-A\&H graduates differ not only in the likelihood of finding a full-time employment but also in the kind of job they enter. Elias and Purcell (2004a, p. 61) define 'graduate jobs' as “those for which a degree is now regarded as an appropriate entry qualification and in which the jobholder applies 
skills and knowledge acquired via a higher education". They divide graduate jobs into Traditional, modern, new and niche ${ }^{\mathrm{xix}}$. As Table 3 shows, $53.92 \%$ of non-A\&H graduates are in non-graduate jobs compared to $67.61 \%$ of $\mathrm{A} \& \mathrm{H}$ graduates. This is particularly important as it suggest that $46.08 \%$ of A\&H graduates end up in a job which does not require a degree and which they cannot apply the knowledge acquired during their studies.

\subsection{The role of $A \& H$ graduates in the creative economy}

After exploring the general profile of $\mathrm{A} \& \mathrm{H}$ students and graduates, it is now interesting to look at their connection with the creative economy. Table 4 shows the percentage of A\&H graduates - divided in sub-groups - who are in creative jobs and it also classifies the 'type' of creative job they are in, i.e. specialised, supportive or embedded (NESTA, 2008).

Table 4: Creative Jobs and Creative Type by Subject

\begin{tabular}{|lcc|ccc}
\hline & $\begin{array}{l}\text { No of } \\
\text { obs }\end{array}$ & $\begin{array}{l}\text { \% } \\
\text { Creative } \\
\text { job }\end{array}$ & \%Specialised & $\begin{array}{l}\text { \% } \\
\text { supportive }\end{array}$ & \%Embedded \\
\hline Non Arts and Humanities & 103,088 & 10.58 & 2.60 & 2.71 & 5.26 \\
\hline $\begin{array}{l}\text { Arts and Humanities } \\
\quad \text { Architecture Building and Planning }\end{array}$ & 45,558 & 26.74 & 11.95 & 6.47 & 8.35 \\
$\quad \begin{array}{l}\text { Mass Communications } \\
\text { and Documentation }\end{array} \quad 4,114$ & 48.49 & 33.3 & 8.41 & 6.86 \\
$\quad$ Creative Arts and Design & 4,823 & 36.33 & 15.04 & 9.52 & 11.76 \\
$\quad$ Historical and Philosophical studies & 15,511 & 38.33 & 17.42 & 7.83 & 13.12 \\
$\quad$ Languages & 7,066 & 14.21 & 4.35 & 5.4 & 4.48 \\
$\quad$ Law & 10,512 & 16.35 & 5.9 & 5.05 & 5.41 \\
\hline Total & 4,532 & 5.56 & 1.13 & 2.21 & 2.23 \\
\hline
\end{tabular}

It is interesting to note that $47 \%$ of 'supportive' jobs are non-graduate, which may imply that graduates entering supportive roles are doing so as a way to break into a creative industry (table 5). A very low percentage of specialised and embedded jobs are non-graduate jobs suggesting that these types of roles do indeed require graduates. A large proportion of specialised and embedded creative jobs tend to be graduate 'modern' or 'new', while 'supportive' jobs are more likely to be 'niche' jobs, which is different to non-creative jobs graduate jobs, which are more likely to be traditional or niche jobs. This 
suggests that the creative economy are using graduates in areas that traditionally graduates would not have entered, and in a different way to non-creative sectors, and highlights the potential importance of graduates from non-traditional fields for the creative sector.

Table 5: Relationship between type of creative job and level of job (graduate type vs. non-graduate)

\begin{tabular}{lcccccc}
\hline & Traditional & Modern & New & Niche & $\begin{array}{l}\text { Non- } \\
\text { graduate }\end{array}$ & Total \\
\hline Specialised & 6.56 & 43.7 & 27.81 & 19.24 & 2.69 & 100.00 \\
\hline $\begin{array}{l}\text { Supported } \\
\text { Embedded }\end{array}$ & 8.35 & 5.1 & 15.33 & 24.5 & 46.73 & 100.00 \\
$\begin{array}{l}\text { Non- } \\
\text { creative }\end{array}$ & 12.10 & 9.43 & 13.02 & 24.76 & 40.69 & 100.00 \\
Total & 11.12 & 13.05 & 15.39 & 23.87 & 36.56 & 100.00 \\
\hline
\end{tabular}

Only $15.53 \%$ of all graduates are in a creative job, of which $6.21 \%$ are in an 'embedded' job, $5.47 \%$ in a 'specialised' one and $3.86 \%$ in a 'supportive' role. A\&H graduates are three times more likely to be in a creative job than non-A\&H graduates (26.74\% vs. $10.58 \%$ ), which means that almost three quarters of A\& $\mathrm{H}$ graduates do not enter a creative job. A\&H graduates - especially those in 'Architecture, Building and Planning' - are the most likely to find a creative job especially in a specialised role. 'Mass Communications' and 'Creative Arts' students have the greatest proportion of students in embedded jobs i.e. in creative occupations outside of the creative industries, but they are also most likely to be in supportive roles, which may be a means for individuals to break into an industry. These relationships between subject studied and the type of creative job found is robust even when we estimate a multinomial logit model in which we include a list of personal, regional and degree characteristics (Table 6), and, in fact even stronger in some cases. Those in 'Architecture, Building and Planning', for instance, are twenty one times more likely to be in a specialised creative job once controlling for other characteristics. 
Table 6: Results of a Multinomial Logit on Creative Job Type (odds ratios with non-Creative Jobs as reference category)

\begin{tabular}{|c|c|c|c|}
\hline & Specialised & Supportive & Embedded \\
\hline \multirow[t]{2}{*}{ Female } & $0.475 * * *$ & $0.686^{* * *}$ & $0.467 * * *$ \\
\hline & {$[-19.251]$} & {$[-9.567]$} & {$[-19.656]$} \\
\hline \multirow[t]{2}{*}{$22-24$} & 1.075 & $1.080 *$ & $1.249 * * *$ \\
\hline & [1.629] & [1.792] & {$[4.430]$} \\
\hline \multirow[t]{2}{*}{$25-34$} & $0.845^{* *}$ & $0.875^{*}$ & 1.099 \\
\hline & {$[-2.372]$} & {$[-1.811]$} & {$[1.303]$} \\
\hline \multirow[t]{2}{*}{$35+$} & $0.541 * * *$ & $0.459 * * *$ & $0.632 * * *$ \\
\hline & {$[-6.349]$} & {$[-7.956]$} & {$[-4.964]$} \\
\hline \multirow[t]{2}{*}{ Disabled } & $1.214 * * *$ & 1.079 & $1.129 * *$ \\
\hline & {$[4.278]$} & {$[1.474]$} & {$[2.476]$} \\
\hline \multicolumn{4}{|c|}{ Ethnicity (ref: white) } \\
\hline \multirow[t]{2}{*}{ Black } & $0.791 * *$ & 0.991 & $0.845^{* *}$ \\
\hline & {$[-2.024]$} & {$[-0.095]$} & {$[-2.245]$} \\
\hline \multirow[t]{2}{*}{ Asian } & 0.961 & 0.907 & 1.097 \\
\hline & {$[-0.420]$} & {$[-1.068]$} & {$[1.564]$} \\
\hline \multirow[t]{2}{*}{ Mixed } & 1.056 & 0.937 & 1.071 \\
\hline & {$[0.530]$} & {$[-0.485]$} & {$[0.642]$} \\
\hline \multirow[t]{2}{*}{ Other } & 1.007 & 0.925 & $1.332 * *$ \\
\hline & {$[0.052]$} & {$[-0.466]$} & [2.395] \\
\hline
\end{tabular}

Subject group (ref: non-Arts and Humanities)

Architecture Building and Planning

$20.872 * * * \quad 4.985 * * * \quad 1.993 * * *$

Mass Communications and

[13.416] [8.340] [3.147]

Documentation

$8.945 * * * \quad 4.548 * * * \quad 3.232 * * *$

[20.179] [17.937] [10.223]

Creative Arts and Design

$10.097 * * * \quad 3.923 * * * \quad 3.682 * * *$

Historical and Philosophical studies

[27.426] [19.599] [18.359]

$1.474 * * * \quad 1.834 * * * \quad 0.801 * * *$

Languages

[4.337]

[7.875]

[-2.834]

$2.430 * * *$

$1.830 * * *$

$1.172 *$

[11.895]

[8.969]

[1.924]

Law

$0.428 * * *$

$0.726 * * *$

$0.418 * * *$

[-4.487]

[-2.931]

[-8.102]

Degree classification (ref: Upper second)

First

$1.671^{* * *} \quad 1.105^{* *} \quad 1.567 * * *$

Lower second

[11.872]

[2.073]

[11.968]

$0.629 * * *$

$0.776 * * *$

$0.654 * * *$

[-11.915]

[-8.451]

[-15.496]

Third/pass

$\begin{array}{lll}0.507 * * * & 0.731 * * * & 0.537 * * * \\ {[-8.875]} & {[-4.373]} & {[-9.095]}\end{array}$ 


\begin{tabular}{llll} 
Other degree class & $0.604 * * *$ & $0.335^{* * *}$ & $0.341^{* * *}$ \\
& {$[-2.833]$} & {$[-5.737]$} & {$[-6.562]$} \\
Institution Type (ref: New University) & & & \\
Russell group & $1.379 * * *$ & 1.128 & 0.896 \\
& {$[3.175]$} & {$[1.391]$} & {$[-1.610]$} \\
Other old & 1.12 & 1.066 & 1.036 \\
& {$[1.097]$} & {$[0.807]$} & {$[0.454]$} \\
HE/FE Colleges & 1.024 & $0.834 * *$ & $0.751^{* *}$ \\
& {$[0.174]$} & {$[-2.107]$} & {$[-2.191]$} \\
& & & \\
\hline Observations & 138,895 & 138,895 & 138,895 \\
Log likelihood & $-75,744$ & $-75,744$ & $-75,744$ \\
LR Chi2 & 26,986 & 26,986 & 26,986 \\
pseudo r-squared & 0.1 & 0.1 & 0.1 \\
\hline
\end{tabular}

Standard errors clustered at institution level, robust $\mathrm{z}$ statistics in brackets

$* * * \mathrm{p}<0.01, * * \mathrm{p}<0.05, * \mathrm{p}<0.1$

Includes region of study dummies (ref: South East)

Among the control variables some results are also worth mentioning. Female A\&H graduates are more likely to be in a non-creative job and so are older graduates and graduate with a black ethnic background. The 'best' A\&H graduates, i.e. those graduating with a 'first' are more likely to find a creative job especially if specialised or embedded (both types are within the creative industries). These graduates are the first in the labour market 'queue' and hence more likely to be able to select their desired sector and the one which best matching their degrees. Surprisingly, however, graduates from Russell group HEIs are more likely to be in creative specialised or supportive jobs, but not in embedded ones. This might be linked with the subject composition of their student body, with many students in subjects such as history, philosophy, law and languages, but few in creative subjects (see Table 2).

It is also worthwhile examining which graduates the creative sectors are most likely to employ (table 7). All creative sectors, but Software and Advertising are more likely to employ A\&H graduates. There is a relatively good match between the 'Design' sector and graduates in 'Creative Arts and Design' (79.86\%), although this is also the group of students with the highest level of self-employment. 'Creative Arts and Design' graduates also popular in the Film, TV, Radio and Photography and Music, 
and Visual Performing Arts sectors. The 'Architecture and Design Engineer' sector is most likely to employ 'Architecture, Building and Planning' graduates but it also employs $41.56 \%$ non-A\&H graduates. Very few A\&H graduates enter the Software industry which is overwhelmingly dominated by non-A\&H graduates (mainly mathematics and IT graduates who account for $64.90 \%$ of the graduates entering this industry).

Table 7: Graduates employed in the creative economy (\% by sub-sector)

\begin{tabular}{lcccccccc}
\hline & $\begin{array}{l}\text { ADV } \\
(\boldsymbol{\%})\end{array}$ & $\begin{array}{l}\text { ARCH } \\
(\boldsymbol{\%})\end{array}$ & $\begin{array}{l}\text { DESIGN } \\
(\boldsymbol{\%})\end{array}$ & $\begin{array}{l}\text { FILM } \\
(\boldsymbol{\%})\end{array}$ & $\begin{array}{l}\text { MUSIC } \\
(\boldsymbol{\%})\end{array}$ & $\begin{array}{l}\text { PUB } \\
(\boldsymbol{\%})\end{array}$ & $\begin{array}{l}\text { SOFT } \\
(\boldsymbol{\%})\end{array}$ & $\begin{array}{l}\text { LIB } \\
(\boldsymbol{\%})\end{array}$ \\
\hline Non Arts and Humanities & 57.31 & 41.56 & 20.14 & 28.09 & 22.4 & 34.08 & 91.45 & 36.44 \\
\hline $\begin{array}{l}\text { Arts and Humanities } \\
\quad \text { Architecture Building and Planning }\end{array}$ & 42.69 & 58.44 & 79.86 & 71.91 & 77.6 & 65.92 & 8.55 & 63.56 \\
$\quad \begin{array}{l}\text { Mass Communications } \\
\text { and Documentation }\end{array}$ & 13.06 & 0.35 & 2.8 & 20.6 & 6.29 & 19.03 & 2.00 & 6.83 \\
$\quad \begin{array}{l}\text { Creative Arts and Design } \\
\quad \begin{array}{l}\text { Historical and Philosophical } \\
\text { studies }\end{array}\end{array}$ & 8.37 & 5.01 & 72.88 & 37.48 & 52.74 & 14.04 & 2.51 & 16.15 \\
$\quad \begin{array}{l}\text { Languages } \\
\text { Law }\end{array}$ & 6.23 & 1.26 & 1.57 & 4.22 & 5.12 & 8.42 & 1.37 & 21.73 \\
\hline & 12.81 & 0.77 & 1.33 & 8.48 & 12.33 & 22.12 & 1.82 & 15.87 \\
\hline
\end{tabular}

Finally, the table below (Table 8) shows the regional distribution of graduates in creative jobs. Greater London clearly plays a more important role for A\&H graduates with about $36 \%$ of them employed in the capital compared to $28 \%$ for non-A\&H graduates. The role played by Greater London is not only confined to the more creative subjects. In fact, graduates in creative jobs from more traditional subjects - in which Russell group HEIs seem to specialise - are even more likely to be employed in the capital than other A \& H graduates. Over 40\% of graduates from 'Historical and Philosophical studies', 'Languages' and 'Law' works in the capital in creative jobs. A high percentage of graduates in creative jobs also work in the South East. Among the maybe less expected results is the relatively high percentage of 'Architecture, Building and Planning graduates' working in Scotland and the North West. 
Table 8: Regional distribution of Creative Jobs by Subject

\begin{tabular}{|c|c|c|c|c|c|c|c|c|c|}
\hline Location of creative job & $\begin{array}{l}\text { Non Arts } \\
\text { and } \\
\text { Humanities }\end{array}$ & $\begin{array}{l}\text { Arts and } \\
\text { Humanities }\end{array}$ & $\begin{array}{l}\text { Architecture } \\
\text { Building } \\
\text { and } \\
\text { Planning }\end{array}$ & $\begin{array}{l}\text { Mass } \\
\text { Communications } \\
\text { and } \\
\text { Documentation }\end{array}$ & $\begin{array}{l}\text { Creative } \\
\text { Arts and } \\
\text { Design }\end{array}$ & $\begin{array}{l}\text { Historical } \\
\text { and } \\
\text { Philosophical } \\
\text { studies }\end{array}$ & Languages & Law & All \\
\hline North East & 3.50 & 2.63 & 2.94 & 2.15 & 2.74 & 1.94 & 2.55 & 4.98 & 3.05 \\
\hline North West & 9.24 & 9.06 & 13.37 & 9.27 & 8.84 & 6.88 & 7.28 & 7.05 & 9.15 \\
\hline $\begin{array}{l}\text { Yorkshire and The } \\
\text { Humber }\end{array}$ & 7.28 & 5.82 & 6.3 & 6.75 & 5.65 & 6.45 & 4.91 & 4.15 & 6.52 \\
\hline East Midlands & 5.40 & 4.7 & 4.69 & 5.28 & 5.24 & 3.33 & 2.81 & 6.22 & 5.03 \\
\hline West Midlands & 6.47 & 5.58 & 5.04 & 6.14 & 5.84 & 5.16 & 5.04 & 4.56 & 6.01 \\
\hline East of England & 6.43 & 5.7 & 5.04 & 4.79 & 5.84 & 5.91 & 6.76 & 4.98 & 6.05 \\
\hline London & 27.59 & 36.2 & 22.39 & 37.75 & 36.28 & 43.23 & 42.63 & 36.93 & 32.08 \\
\hline South East & 14.42 & 11.25 & 9.73 & 10.01 & 11.35 & 10.86 & 13.53 & 13.28 & 12.77 \\
\hline South West & 7.39 & 7.2 & 7.7 & 7.06 & 7.83 & 4.41 & 6.57 & 6.22 & 7.29 \\
\hline Wales & 3.10 & 3.5 & 3.71 & 3.31 & 3.8 & 3.23 & 2.62 & 3.73 & 3.31 \\
\hline Scotland & 6.60 & 6.66 & 14.77 & 6.14 & 5.57 & 6.45 & 4.08 & 3.73 & 6.63 \\
\hline Northern Ireland & 2.56 & 1.68 & 4.34 & 1.35 & 1.03 & 2.15 & 1.21 & 4.15 & 2.11 \\
\hline Total & 100 & 100 & 100 & 100 & 100 & 100 & 100 & 100 & 100 \\
\hline
\end{tabular}




\subsection{Labour market outcomes of A\&H graduates}

A\&H graduates earn, on average, less than non-A\&H ones. As Table 9 shows, the difference between the average salaries of $A \& H$ and non- $A \& H$ graduates is about $£ 3,000$. However, there are considerable differences between sub-groups within the A\&H category.

'Architecture, Building and Planning' graduates fair particularly well with an average salary even higher than the average of non-A\&H graduates ( $£ 20,723$ vs. $£ 19,002)$ and do better either in supportive or non-creative roles. 'Creative Arts and Design' graduates are the ones with the lowest labour market rewards, even though they tend to do better if they can find employment within the creative sector (especially in an 'embedded' job). This is consistent with previous findings (Comunian et al. 2010). Although slightly better off, 'Mass Communications and Documentation' graduates have a similar profile to the 'Creative Arts and Design' ones.

Table 9: Salaries by Subject and Creative Job Type

\begin{tabular}{|c|c|c|c|c|c|c|}
\hline \multirow[b]{2}{*}{ Subject group } & \multicolumn{6}{|c|}{ Mean Salary $(\mathfrak{f})$} \\
\hline & All & $\begin{array}{c}\text { Creative } \\
\text { Job }\end{array}$ & Specialised & Supportive & Embedded & $\begin{array}{c}\text { Non- } \\
\text { Creative }\end{array}$ \\
\hline Non Arts and Humanities & 19,002 & 19,533 & 19,405 & 17,955 & 20,307 & 18,936 \\
\hline Arts and Humanities & 16,218 & 16,319 & 16,165 & 16,336 & 16,493 & 16,182 \\
\hline Architecture Building and Planning & 20,723 & 18,043 & 16,910 & 21,938 & 18,702 & 23,197 \\
\hline $\begin{array}{l}\text { Mass Communications and } \\
\text { Documentation }\end{array}$ & 15,171 & 16,232 & 15,935 & 15,796 & 16,827 & 14,431 \\
\hline Creative Arts and Design & 14,751 & 15,531 & 15,551 & 15,008 & 15,782 & 14,280 \\
\hline Historical and Philosophical studies & 16,623 & 16,822 & 17,332 & 16,042 & 17,198 & 16,591 \\
\hline Languages & 16,128 & 16,199 & 16,172 & 15,668 & 16,656 & 16,114 \\
\hline Law & 17,289 & 18,325 & 17,353 & 19,074 & 17,960 & 17,227 \\
\hline All graduates & 18,274 & 18,073 & 17,499 & 17,214 & 18,951 & 18,312 \\
\hline
\end{tabular}

With the exception of 'Architecture, Building and Planning', entering a graduate job brings - on average - greater rewards than being in a non-creative job. In general, being in an 'embedded' job (i.e. a creative occupation outside of the creative industries) brings slightly higher economic rewards for $\mathrm{A} \& \mathrm{H}$ graduates, although looking at the sub-group breakdown, we can notice some exceptions. 'Architecture, 
Building and Planning' and 'Law' graduates fair better in supportive jobs, whilst 'Historical and Philosophical' graduates fair better in specialised roles. The result on 'Law' graduates, however, should be taken cautiously as not a very high proportion of Law graduates enter a creative job and many of them are enrolled in further studies.

The differences between average salaries in different creative jobs and for graduates in different subjects could, however, be linked to different personal characteristics of students and graduates. It is, therefore, important to control for these individual characteristics when assessing the differences between sectors and/or subjects salaries. Table 10 presents the results of a salary OLS regression where all the different components have been included.

Table 10: Results of robust OLS salary regression Dependent variable: LN (Salary)

\begin{tabular}{|c|c|c|c|c|}
\hline & All & $\begin{array}{l}\text { Excluding PT } \\
\text { Workers }\end{array}$ & $\begin{array}{l}\text { All - } \\
\text { Creative Job }\end{array}$ & All - AH only \\
\hline \multicolumn{5}{|l|}{ Personal Characteristics } \\
\hline Female & $\begin{array}{l}-0.044 * * * \\
{[-10.723]}\end{array}$ & $\begin{array}{l}-0.052 * * * \\
{[-12.814]}\end{array}$ & $\begin{array}{l}-0.046^{* * * *} \\
{[-7.241]}\end{array}$ & $\begin{array}{l}-0.025 * * * \\
{[-4.327]}\end{array}$ \\
\hline \multicolumn{5}{|l|}{ Age on graduation (ref: 21 and under) } \\
\hline $22-24$ & $\begin{array}{l}0.088 * * * \\
{[17.801]}\end{array}$ & $\begin{array}{l}0.090 * * * \\
{[17.953]}\end{array}$ & $\begin{array}{l}0.049 * * * \\
{[7.076]}\end{array}$ & $\begin{array}{l}0.052 * * * \\
{[8.522]}\end{array}$ \\
\hline $25-34$ & $\begin{array}{l}0.240 * * * \\
{[30.583]}\end{array}$ & $\begin{array}{l}0.238 * * * \\
{[29.753]}\end{array}$ & $\begin{array}{l}0.155^{* * *} \\
{[12.738]}\end{array}$ & $\begin{array}{l}0.182^{* * *} \\
{[14.051]}\end{array}$ \\
\hline $35+$ & $\begin{array}{l}0.383 * * * \\
{[36.207]}\end{array}$ & $\begin{array}{l}0.377 * * * \\
{[32.758]}\end{array}$ & $\begin{array}{l}0.272 * * * \\
{[13.631]}\end{array}$ & $\begin{array}{l}0.316 * * * \\
{[16.289]}\end{array}$ \\
\hline Disabled & $\begin{array}{l}-0.028 * * * \\
{[-6.655]}\end{array}$ & $\begin{array}{l}-0.026 * * * \\
{[-5.507]}\end{array}$ & $\begin{array}{l}-0.004 \\
{[-0.390]}\end{array}$ & $\begin{array}{l}-0.013 \\
{[-1.520]}\end{array}$ \\
\hline \multicolumn{5}{|l|}{ Ethnicity (ref: white) } \\
\hline Black & $\begin{array}{l}-0.050 * * * \\
{[-6.302]}\end{array}$ & $\begin{array}{l}-0.043 * * * \\
{[-5.650]}\end{array}$ & $\begin{array}{l}-0.004 \\
{[-0.182]}\end{array}$ & $\begin{array}{l}-0.015 \\
{[-0.790]}\end{array}$ \\
\hline Asian & $\begin{array}{l}-0.01 \\
{[-1.083]}\end{array}$ & $\begin{array}{l}-0.008 \\
{[-0.868]}\end{array}$ & $\begin{array}{l}0.005 \\
{[0.467]}\end{array}$ & $\begin{array}{l}-0.015 \\
{[-0.974]}\end{array}$ \\
\hline Mixed & $\begin{array}{l}-0.025 * * \\
{[-2.601]}\end{array}$ & $\begin{array}{l}-0.019^{*} \\
{[-1.956]}\end{array}$ & $\begin{array}{l}-0.009 \\
{[-0.460]}\end{array}$ & $\begin{array}{l}-0.01 \\
{[-0.600]}\end{array}$ \\
\hline Other & $\begin{array}{l}-0.013 \\
{[-0.641]}\end{array}$ & $\begin{array}{l}0.004 \\
{[0.174]}\end{array}$ & $\begin{array}{l}-0.038 \\
{[-0.811]}\end{array}$ & $\begin{array}{l}-0.106 * * * \\
{[-3.295]}\end{array}$ \\
\hline \multicolumn{5}{|c|}{ Subject group (ref: non-Arts and Humanities) } \\
\hline Architecture Building and Planning & $0.086^{* * *}$ & $0.085 * * *$ & $-0.076^{* * *}$ & $0.275^{* * *}$ \\
\hline
\end{tabular}




\begin{tabular}{|c|c|c|c|c|}
\hline & [4.100] & [4.124] & {$[-3.990]$} & [16.197] \\
\hline \multirow[t]{2}{*}{ Documentation } & $-0.111 * * *$ & $-0.107 * * *$ & $-0.053 * * *$ & $-0.029 * *$ \\
\hline & {$[-13.321]$} & {$[-12.853]$} & {$[-4.375]$} & {$[-2.473]$} \\
\hline \multirow[t]{2}{*}{ Creative Arts and Design } & $-0.157 * * *$ & $-0.158 * * *$ & $-0.107 * * *$ & $-0.067^{* * *}$ \\
\hline & {$[-22.841]$} & {$[-22.528]$} & {$[-11.602]$} & {$[-6.049]$} \\
\hline \multirow[t]{2}{*}{ Historical and Philosophical studies } & $-0.127 * * *$ & $-0.128 * * *$ & $-0.090^{* * *}$ & -0.009 \\
\hline & {$[-16.413]$} & {$[-17.044]$} & {$[-6.511]$} & {$[-0.847]$} \\
\hline \multirow[t]{2}{*}{ Languages } & $-0.113 * * *$ & $-0.110 * * *$ & $-0.089 * * *$ & \\
\hline & {$[-13.470]$} & {$[-12.084]$} & {$[-7.137]$} & \\
\hline \multirow[t]{2}{*}{ Law } & $-0.056^{* * *}$ & $-0.059 * * *$ & 0.008 & $0.053^{* * *}$ \\
\hline & {$[-5.158]$} & {$[-5.118]$} & {$[0.225]$} & [4.123] \\
\hline \multicolumn{5}{|c|}{ Creative job type (ref: non-creative job) } \\
\hline \multirow[t]{2}{*}{ Specialised } & $-0.019 * *$ & $-0.024 * * *$ & & $0.027 * *$ \\
\hline & {$[-2.099]$} & {$[-2.707]$} & & {$[2.130]$} \\
\hline \multirow[t]{2}{*}{ Supportive } & 0.001 & 0 & -0.004 & $0.065^{* * *}$ \\
\hline & [0.046] & {$[-0.037]$} & {$[-0.346]$} & [3.995] \\
\hline \multirow[t]{2}{*}{ Embedded } & $0.049 * * *$ & $0.046^{* * *}$ & $0.048 * * *$ & $0.096 * * *$ \\
\hline & [7.148] & {$[6.522]$} & [7.591] & [8.983] \\
\hline \multicolumn{5}{|c|}{ Creative core sector (ref: Advertising) } \\
\hline \multirow[t]{2}{*}{ Architecture } & $-0.026^{*}$ & $-0.030 * *$ & $0.080 * * *$ & $-0.187 * * *$ \\
\hline & {$[-1.894]$} & {$[-2.059]$} & [7.901] & {$[-8.588]$} \\
\hline \multirow[t]{2}{*}{ Design } & $-0.021 * *$ & $-0.020 * *$ & $-0.043^{* * *}$ & $-0.046 * * *$ \\
\hline & {$[-2.255]$} & {$[-2.155]$} & {$[-4.398]$} & {$[-3.429]$} \\
\hline \multirow[t]{2}{*}{ Film } & $-0.080 * * *$ & $-0.084 * * *$ & $-0.094 * * *$ & $-0.104 * * *$ \\
\hline & {$[-6.721]$} & {$[-6.669]$} & {$[-8.008]$} & {$[-6.923]$} \\
\hline \multirow[t]{2}{*}{ Music } & $-0.055 * * *$ & $-0.061 * * *$ & $-0.067 * * *$ & $-0.073 * * *$ \\
\hline & {$[-3.658]$} & {$[-3.782]$} & {$[-4.964]$} & {$[-3.981]$} \\
\hline \multirow[t]{2}{*}{ Publishing } & $-0.038 * * *$ & $-0.037 * * *$ & $-0.046^{* * *}$ & $-0.067 * * *$ \\
\hline & {$[-3.709]$} & {$[-3.656]$} & {$[-4.393]$} & {$[-5.665]$} \\
\hline \multirow[t]{2}{*}{ Software } & $0.089 * * *$ & $0.087 * * *$ & $0.109 * * *$ & $0.067^{* * *}$ \\
\hline & [8.965] & {$[8.740]$} & {$[10.603]$} & [2.940] \\
\hline \multirow[t]{2}{*}{ Libraries } & $-0.137 * * *$ & $-0.156^{* * *}$ & $-0.152 * * *$ & $-0.135^{* * *}$ \\
\hline & {$[-8.385]$} & {$[-8.328]$} & {$[-9.505]$} & {$[-5.971]$} \\
\hline \multicolumn{5}{|c|}{ Degree classification (ref: Upper second) } \\
\hline \multirow[t]{2}{*}{ First } & $0.049 * * *$ & $0.050 * * *$ & $0.039 * * *$ & $0.022 * * *$ \\
\hline & [11.012] & [11.344] & {$[7.128]$} & {$[3.217]$} \\
\hline \multirow[t]{2}{*}{ Lower second } & $-0.032 * * *$ & $-0.032 * * *$ & $-0.036^{* * *}$ & $-0.026 * * *$ \\
\hline & {$[-8.547]$} & {$[-8.577]$} & {$[-5.872]$} & {$[-4.144]$} \\
\hline \multirow[t]{2}{*}{ Third/pass } & -0.017 & -0.018 & $-0.039 * *$ & $-0.042 * *$ \\
\hline & {$[-0.699]$} & {$[-0.708]$} & {$[-2.319]$} & {$[-2.595]$} \\
\hline \multirow[t]{2}{*}{ Other degree class } & $0.223 * * *$ & $0.232 * * *$ & -0.006 & -0.003 \\
\hline & [7.141] & [7.329] & {$[-0.242]$} & {$[-0.099]$} \\
\hline \multicolumn{5}{|l|}{ Institution Type (ref: New University) } \\
\hline Russell group & $0.090 * * *$ & $0.091 * * *$ & $0.039 * * *$ & 0.02 \\
\hline & [8.376] & [8.087] & [3.204] & [1.621] \\
\hline
\end{tabular}




\begin{tabular}{lllll} 
Other old & $0.022^{* *}$ & $0.021 * *$ & $0.024 * *$ & 0.005 \\
& {$[2.292]$} & {$[2.131]$} & {$[2.046]$} & {$[0.314]$} \\
HE/FE Colleges & -0.006 & -0.007 & -0.001 & 0.002 \\
& {$[-0.517]$} & {$[-0.600]$} & {$[-0.115]$} & {$[0.162]$} \\
Job Attributes & & & & \\
Part time & $-0.261 * * *$ & & $-0.191 * * *$ & $-0.246 * * *$ \\
& {$[-33.708]$} & & {$[-12.460]$} & {$[-24.702]$} \\
Freelance/self employed & 0.019 & 0.02 & -0.02 & 0.013 \\
& {$[0.997]$} & {$[1.072]$} & {$[-0.865]$} & {$[0.509]$} \\
\hline Observations & 59,719 & 55,178 & 9,270 & 15,730 \\
R-squared & 0.326 & 0.31 & 0.342 & 0.297 \\
\hline
\end{tabular}

Standard errors clustered at institution level, robust $t$ statistics in brackets

$* * * \mathrm{p}<0.01, * * \mathrm{p}<0.05, * \mathrm{p}<0.1$

1 - when no non-creative jobs the reference group is specialised

Includes region of employment dummies

Most of the results on the control variables are consistent with theoretical expectations. The older and the better (in terms of final degree classification) the graduates the higher are their salaries, consistently to what the human capital theory predicts (Becker 1993). As mentioned in the analysis of Table 2b, we seems to have a 'signalling' effect as a higher salary is also associated with courses at a Russell group or 'old' HEI (however this is not significant with A \& H students). Female graduates and those belonging to ethnic minorities are at a salary disadvantage, possibly due to factors related to labour market discrimination. As far as location of first job is concerned (although not presented in Table 10), London and the South East are the most favourable regions, while the least advantageous are Scotland and Northern Ireland (which are also the most peripheral).

The results on subject groups remain robust with the findings in Table 9 even after including all the control variables, i.e. although generally $\mathrm{A} \& \mathrm{H}$ graduates earn less than non-A\&H, 'Architecture, Building and Planning' is an exception. 'Creative Arts and Design' graduates are, economically, the worst off. However, if we look at only creative jobs again A \& H graduates are worse off than non A \& $\mathrm{H}$ graduates.

Finally, creative embedded jobs are associated with higher salaries than non-creative positions, while the opposite holds for specialised ones. If we look at the creative sectors of employment, the software 
sector, followed by advertising - which are the ones employing the lowest percentage of $\mathrm{A} \& \mathrm{H}-$ offers the highest salary across all sectors. If we only examine A \& $\mathrm{H}$ students then being in any of the creative job types pays on average more than being in a non-creative job, especially embedded, with software and advertising being the highest paid sectors.

\section{Conclusions and policy implications}

The paper has explored and highlighted the employment dynamics of A\&H graduates in the UK, with a particular attention to their relationship with the creative economy. Although most of the recent policy debate on the role of HEIs has focused on knowledge transfer and knowledge spillovers, we believe that the main role of HEIs is in producing high quality graduates who can fit and be productive in the labour market. Focusing specifically on the creative economy, the employability and ability of A\&H graduates to access the creative labour market is one of the pillars to make the sector a success story. Moreover, the degree of 'embeddedness' of these graduates within the creative economy and its associated industries is also important. The paper offers a classification of creative jobs based on their degree of embeddedness within the creative sector and question whether $\mathrm{A} \& \mathrm{H}$ graduates are embedded in the sector. The results suggest that $\mathrm{A} \& \mathrm{H}$ graduates are strongly embedded in the UK creative economy as they are three time more likely to be in a creative job than non-A\&H graduates. However only $25 \%$ of A\& $\mathrm{H}$ graduates find work in the creative sector.

However, the paper also highlights how complex the creative economy and its links with the HEIs are. The so-called creative industries are a collection of very heterogeneous sectors, which demand very different skills from graduates and offer in return very different working conditions. Looking specifically at A\&H graduates, we showed how the intersection between the different sub-disciplines of A\&H and the creative economy is a complex phenomenon, with graduates from some sub-disciplines- 
like ‘Architecture, Building and Planning', 'Mass Communication' and 'Creative Arts' - strongly present in specialised jobs within the creative economy, while others - such a 'Historical and Philosophical studies' and 'Law' graduates - more likely to be in supportive roles. 'Embedded' positions (i.e. creative jobs outside the creative industries) are important for 'Mass Communication', 'Creative Arts and Design' and 'Language' graduates. This complex interconnection with the creative economy highlights a degree of flexibility amongst A\&H graduates - especially as often their career patterns are not as structured as in other fields (although 'Law' and 'Architecture, Building and Planning' are exceptions to this).

There are some important observations emerging from the findings of the paper that need the attention of policy makers in the UK. Firstly, the relationship between A\&H and technology-based creativity is questioned in our data. While anecdotal evidence exists on the importance of creative arts skills in the game industry, the software sector (as defined by the DCMS) employs very few A\&H graduates. This might seem obvious as STEM graduates are probably more prepared to engage with this sector than A\&H graduates. However, as the Software, Computer Games \& Electronic Publishing is the sector with the highest GVA average growth in the creative economy (9\% p.a. compared with a 5\% p.a. growth as average of the creative industries as a whole) as well as being the one covering $33 \%$ of the value of exports and with the highest growth in the employment (5\% in the period 1997-2007 compared with the average growth of $2 \%$ of the whole creative sector - see DCMS, 2010a), the contribution of A\&H graduates to growth seems weaker. In fact, A\&H graduates find jobs more often in sectors of the creative economy which perform worse or equal to the national average. A better understanding of the possible interconnections between $\mathrm{A} \& \mathrm{H}$ graduates and technology-based creative industries and jobs is therefore important. 
Secondly, as in previous work (Comunian et al., 2010; Abreu et al., 2011), even when A\&H graduate gain access to creative jobs, their salaries are lower than non-A\&H graduates in the same jobs. While it is known that the creative sector provides more temporary and unstable positions, it is puzzling that graduates in non-A\&H subjects are paid higher than those in A\&H subjects, whose skills should be a better match for the sector. The importance of the role played by different type of HEIs in determining the salary perspectives (because of either 'signalling' or different 'human capital') of these graduates should not be underestimated and needs to be taken in account by HEIs and policy makers.

Thirdly, it is important from an HE policy perspective to consider how much the 'creative education' is integrated within the overall HE curricula and infrastructure. Hartley (2010) -reflecting on the experience of the Queensland University of Technology in developing the 'Creative Industries Precinct' - argues that the integration of creative research activities and production with a creative education is 'as an essential investment in population-wide innovation for the growth of knowledge' (Hartley, 2010, p.11). It could be argued that a better integration of $A \& H$ knowledge and skills might in fact facilitate the 'embedding' of A\&H graduates within the creative economy. Especially since only $25 \%$ of A\& H graduates find work in the creative sector, which could reflect either A \& $\mathrm{H}$ graduates are under-utilised or that there is an excess supply of A \& $\mathrm{H}$ graduates.

Some caveats do apply to our research. The first and more important one is that our data refers to employment found 6 after graduation. More longitudinal data would be a good complement to our analysis. However, while this is a short time, there is evidence suggesting that this initial performance in the labour market affects the career development of graduates in the longer term (Elias et al. 1999; McKnight 1999; Abreu et al. 2011) 
Secondly, while we sketched a 'national' picture of the situation of A\&H graduates and their embeddedness into the creative economy, we did not provide details on the geographical differences between regions within the UK. Comunian and Faggian (2011) dealt more specifically with the geographical distribution of creative occupations and jobs, even thought their focus was more on 'Bohemian' graduates, i.e. graduates in more artistic subjects, rather than the wider A\&H graduates group. An important step forward will be to integrate the geographical diversity - both in terms of regional differences but also rural-urban differences - into our analysis to provide important policy insights to local actors.

Finally, while our exploration has tried to capture the contribution of A\&H graduates to the creative economy in labour market terms, more research is needed to grasp their contribution in broader cultural and social terms. In particular, we would like to suggest that new attention should be placed on graduates within the current debate taking place on the value of $\mathrm{A} \& \mathrm{H}$ research and knowledge in our society as even more than academics and research outputs they - with their everyday contribution to the economy and society - are the ambassadors to A\&H knowledge.

\section{References}

Abbing, Hans. 2002. Why are artists poor?: the exceptional economy of the arts Amsterdam Amsterdam University Press.

Abreu, Maria, Alessandra Faggian, Roberta Comunian, and Philip McCann. 2011. "Life is short, art is long": the persistent wage gap between Bohemian and non-Bohemian graduates. The Annals of Regional Science:1-17, Online First DOI: 10.1007/s00168-010-0422-4.

Anselin, L, A Varga, and Z Acs. 2000. Geographical Spillovers and University Research: A Spatial Econometric Perspective. Growth and Change 31 (4):501-515.

Araya, D. 2010. Educational Policy in the creative economy. In Education in the creative economy: Knowledge and learning in the age of innovation, edited by D. Araya and M. A. Peters. New York: Peter Lang.

Audretsch, David B., Erik E. Lehmann, and Susanne Warning. 2005. University spillovers and new firm location. Research Policy 34 (7):1113-1122.

Baines, Sue, and L Robson. 2001. Being self-employed or being enterprising? The case of creative work for the media industries. Journal of Small Business and Enterprise Development 8 (4):349-362.

Bakhshi, Hasan, Philippe Schneider, and Christopher Walker. 2008. Arts and Humanities Research and Innovation. Bristol and London: AHRC \& NESTA. 
Becker, G S. 1993. Human Capital: A Theoretical and Empirical Analysis, with Special Reference to Education Chicago: University of Chicago Press.

Brown, P, and A Hesketh, eds. 2004 The Mismanagement of Talent: Employability and Jobs in the Knowledge Economy. Oxford: Oxford University Press.

Bullen, E, S Robb, and J Kenway. 2004. 'Creative Destruction': knowledge economy policy and the future of the arts and humanities in the academy. Journal of Education Policy 19 (1):3 - 22.

Cantor, Nancy. 2005. Collaborations on the Creative "Campus". In Conference on Campus-Community Art Connections and the Creative Economy of Upstate New York. Cornell University, Ithaca, New York.

Chatterton, P. 1999. The cultural role of universities in the community: reivisiting the university community debate. Environment \& Planning A 32:165-181.

Chevalier, A. (2011) Subject Choice ad Earnings of UK Graduates, Economics of Education Review, 30 (6), 1187-1201

Clark, B. R. 1998. The Entrepreneurial University: Demand and Response. Tertiary Education and Management 4 (1):5-16.

Comunian, R. 2009. Questioning creative work as driver of economic development: the case of Newcastle-Gateshead, Creative Industries Journal, 2 (1): 57-71

Comunian, R. 2011. Rethinking the creative city: the role of complexity, networks and interactions in the urban creative economy, Urban Studies, 48(6): 1157-1179

Comunian, R, and A. Faggian. 2011. Higher Education and the Creative City. In Handbook on Cities and Creativity edited by C. Mellander, A. Andersson and D. Andersson. London/ New York: Edward Elgar.

Comunian, R, A. Faggian, and Qian Che Li. 2010. Unrewarded careers in the creative class: The strange case of Bohemian graduates. Papers in Regional Science 89 (2):389 - 410

Comunian, Roberta, D Smith, and C Taylor. forthcoming. The role of universities in the regional creative economy: hidden protagonists and the challenge of knowledge transfer. European Planning Studies.

Cross, E. , and H. Pickering. 2008. The contribution of higher education to regional cultural development in the North East Of England Higher Education Management and Policy 20 (2):125-137 OECD.

Crossick, G. 2009. So who now believes in the transfer of widgets? In Knowledge Futures Conference. Goldsmiths, University of London.

Cunningham, S, T Cutler, G Hearn, M Ryan, and M Keane. 2004. An innovation agenda for the Creative Industries: Where is the R\&D? Media International Australia: incorporating Culture \& Policy 112:174-185.

Cunningham, Stuart, and Luke Jaaniste. 2010. The Policy Journey Toward Education for the Creative Economy. In Education in the Creative Economy, edited by D. Araya and M. A. Peters. New York: Peter Lang.

DCMS. 1999. Creative Industries Exports - Our hidden potential. London: Department for Culture, Media and Sport.

. 2003. Regional Cultural Data Framework. In a report by Positive Solutions, Business Strategies, Burns Owens Partnership and Andy C. Pratt. London: DCMS (Department for Media, Culture and Sport).

.2010a. Creative Industries Economic Estimates. London: DCMS.

.2010b. Creative Industries Economic Estimates: Technical Note. In available online http://webarchive.nationalarchives.gov.uk/+/http://www.culture.gov.uk/images/research/Creati ve_Industries_Economic_Estimates_2010_technica_note.pdf. London: DCMS.

DCMS, and BERR. 2008. Creative Britain - New Talents for the Economy. London: DCMS.

Elias, P., A. Mcknight, K. Purcell, and J. Pitcher, eds. 1999. Moving on: graduate careers three years after graduation. Manchester: CSU/DfEE. 
Etzkowitz, Henry, and Loet Leydesdorff. 2000. The dynamics of innovation: from National Systems and "Mode 2" to a Triple Helix of university-industry-government relations. Research Policy 29 (2):109-123.

Faggian A., Comunian R., Jewell S. and Kelly U. (forthcoming), "Bohemian graduates in UK: disciplines and location determinants of creative careers", Regional Studies

Faggian, A., and P. McCann. 2006. Human capital flows and regional knowledge assets: a simultaneous equation approach. Oxford Economic Papers 58 (3):475-500.

Faggian A., McCann P. and Sheppard S. 2007 "Some evidence that women are more mobile than men: Gender differences in UK graduate migration behavior", Journal of Regional Science, Vol.47 No.3, pp. 517-539

Faggian, A., and P. McCann. 2009a. "Human Capital and Regional Development" in Capello R. and Nijkamp P. (eds.), Handbook of Regional Growth and Development Theories, Edward Elgar, Cheltenham, pp. 131-151

Faggian, A., and P. McCann. 2009b. Human capital, graduate migration and innovation in British Regions. Cambridge Journal of Economics 33:317-333.

Fingleton, B, D.C Igliori, B. Moore, and R Odedra. 2007. Employment Growth and Cluster Dynamics in Creative Industries in Great Britain. In The Economic Geography of Innovation, edited by K. Polenske. Cambridge (UK): Cambridge University Press.

Finnie, R, and M Frenette. 2003. Earning differences by major field of study: evidence from three cohorts of recent Canadian graduates. Economics of Education Review 22:179-192.

Florida, R. 1999. The role of the university: leveraging talent, not technology. Science and Technology Summer, 1999.

Florida, R. 2002a. Bohemia and economic geography. Journal of Economic Geography 2:55-71.

Florida, R. 2002b. The Economic Geography of Talent. Annals of the Association of American Geographers 92 (4):743 - 755.

Florida, R. 2002c. The Rise of the Creative Class, (and how it's transforming work, leisure. community \& everyday life). New York: Basic Books.

Frontier Economics. 2009. Creative industry performance. A statistical analysis for the DCMS. London: DCMS.

Glaeser, E L. 2005. Review of Richard Florida's "The Rise of the Creative Class". Regional Science and Urban Economics 35:593-596.

Hartley, John 2010. Research-led educational renewal and economic-cultural convergence. In The QUT Creative Industries Experience, edited by M. Keane and H. Li. Brisbane: QUT.

Haukka, S. 2011. Education-to-work transitions of aspiring creatives. Cultural Trends 20 (1):41-64.

HM Treasury. 2003. The Lambert review of business-university collaboration. London: The Stationary Office.

Hausman, J. \& McFadden, D. (1984) Specification tests for the multinomial logit model. Econometrica, 52, 1219-1240.

Huggins, R, and A Johnston. 2009. The economic and innovation contribution of universities: a regional perspective. Environment and Planning C: Government and Policy 27:1088 - 1106.

Hughes, Alan, Michael Kitson, Jocelyn Probert, Anna Bullock, and Isobel Milner. 2011. Hidden Connections: Knowledge exchange between the arts and humanities and the private, public and third sectors. Arts \& Humanities Research Council (AHRC) and Centre for Business Research (CBR) at the University of Cambridge.

Jayne, Mark. 2005. Creative industries: the regional dimension? Environment \& Planning C: Government \& Policy 23:537 - 556.

Lindberg, M E. 2008. Higher education-to-work transitions in the knowledge society: the initial transition and positional competition point of view. Higher Education in Europe 33 (4):375385 . 
Mathur, Vijay K. 1999. Human Capital-Based Strategy for Regional Economic Development. Economic Development Quarterly 13 (3):203-216.

McKnight, A. 1999. Graduate employability and performance indicators, first destinations and beyond. In Moving On: Graduate careers three years after graduation, edited by P. Elias, A. Mcknight, K. Purcell and J. Pitcher. Manchester: CSU/DfEE.

Mellander, Charlotta, and R Florida. 2007. The Creative Class or Human Capital? - explaining regional development in Sweden. KTH / CESIS, Electronic Working Paper Series in Economics and Institutions of Innovation Paper No. 79.

Million +. 2008. Creative Futures: Building the Creative Economy through Universities. London: Million +

NESTA. 2008. Beyond the creative industries: mapping the creative economy in the United Kingdom. London: NESTA

NESTA. 2009. The geography of creativity. London: NESTA

Peck, J. 2005. Struggling with the Creative Class. International Journal of Urban and Regional Research 29:740-770.

Pitcher, J. , and K. Purcell. 1998. Diverse Expectations and Access to Opportunities: is there a graduate labour market? Higher Education Quarterly 52 (2):179-203.

Powell, J. 2007. Creative universities and their creative city-regions. Industry and Higher Education 21 (6):323-335.

Pratt, A. 1997. The cultural industries production system: a case study of employment change in Britain, 1984-91. Environment and Planning A 29 (11):1953-1974.

Rogers, A , and L Castro. 1981. Model Migration Schedules. Laxenburg, Austria: International Institute for Applied Systems Analysis.

Rogers, A, R Raquillet, and L Castro. 1978. Model migration scheduales and their applications. Environment and Planning A 10 (5):475-502.

Rothaermel, Frank T., and Marie Thursby. 2005. University-incubator firm knowledge flows: assessing their impact on incubator firm performance. Research Policy 34 (3):305-320.

Shattock, M. 2010. Managing Mass Higher Education in a Period of Austerity. Arts and Humanities in Higher Education 9 (1):22-30.

Stolarick, K, and R Florida. 2006. Creativity, connections and innovation: a study of linkages in the Montréal Region. Environment and Planning A 38 (10):1799 - 1817

Taylor, C. 2006. Beyond Advocacy: Developing an Evidence Base for Regional Creative Industry Strategies. Cultural Trends 15 (1):3 -18.

Train, K. 2003. Discrete Choice Methods with Simulation, Cambridge University Press.

Terranova, Tiziana. 2000. Free Labor: Producing Culture for the Digital Economy. Social Text 18 (2):33-58.

The Economist. 2010. The government's new guru: Bring me sunshine. The sudden popularity of a controversial American economist The Economist

The Work Foundation. 2008. Staying ahead: the economic performance of the UK's creative industries. London: The Work Foundation.

Towse, R. 2001. Partly for the Money: Rewards and Incentives to Artists. KYKLOS 54 (2/3):473-490.

Universities UK. 2010. Creating Prosperity: the role of higher education in driving the UK's creative economy. London Universities UK.

Willetts, D. 2011. The Arts, Humanities and Social Sciences in the Modern University - Speech give on 1st March 2011. edited by M. o. S. f. U. a. Science. British Academy, London. 
${ }^{\mathrm{i}}$ We wished to thank two anonymous referees for their comments and suggestions on a previous version of the paper.

${ }^{\text {ii }}$ For more details see the Browne (2010) report http://www.bis.gov.uk/assets/biscore/corporate/docs/s/10-1208securing-sustainable-higher-education-browne-report.pdf p.49

iii In 2011 the AHRC launched a new initiative 'Knowledge Exchange Hubs for the Creative Economy' investing over $£ 16 \mathrm{~m}$ over four years. These hubs 'will be charged with the task of building new partnerships and entrepreneurial capacity in the Creative Economy and increasing the number of arts and humanities researchers actively engaged in research-based knowledge exchange' (AHRC press release, 16 August 2011 available at http://www.ahrc.ac.uk/News/Latest/Pages/boostforresearchersUKCreativeEconomy.aspx accessed 21/03/2012) iv For a detailed account of this evolution, please see UNCTAD (2010) pages 3 to 19.

v The DCMS (2001) definition of the creative industries includes: advertising, architecture, the art and antiques market, crafts, design, designer fashion, film, interactive leisure software, music, the performing arts, publishing, software and television and radio.

vi 'The Creative Industries grew by an average of 5\% per annum between 1997 and 2007. This compares to an average of 3\% for the whole of the economy over this period' (DCMS, 2010a)

vii The concept of creative class was especially embraced by policy makers. So much so that in 2010 the Economist called Florida the new 'guru' of the UK government on issues related to the creative economy.

viii For a thorough discussion of the links between HEIs, human capital and regional development see Faggian and McCann 2009a

ix The 'creative or bohemian graduates' category is a sub-group of the A\&H graduates which has been the focus of recent papers (Comunian et al. 2010; Comunian et al. 2011) and broadly correspond to graduate in the creative arts disciplines.

${ }^{x}$ The response rate to the DLHE survey for the 2005 cohort was $77 \%$ for undergraduates, $62 \%$ for postgraduates and $58 \%$ for undergraduates below first degree level.

xi For more information on the Joint Academic Coding System (JACS) see http://www.hesa.ac.uk/index.php?option=com_content\&task=view\&id=158\&Itemid=233

xii The only exception is a slight over-representation of Arts and Humanities 
xiii For a more detailed description of the codes see Comunian et al. (2010)

${ }^{\text {xiv }}$ In our analysis the following changes to SOC codes (Creative Occupations) are applied: we exclude 1136 (Information and Communication Technology managers) but include 2132 (Software professionals) as part of Software, Computer and electronic Publishing; we include 2451 - librarians, 2452 - Archivists and curators and 4135 - Library assistants/clerks, since this occupation is likely to be important in the context of Arts and Humanities graduates; we exclude 9121 - Labourers, build \& woodworking trades from crafts occupation, due to only a small proportion being creative occupations as also stated by the DCMS. NESTA (2008) excluded 12 other occupations used by the DCMS definition, beyond those already mention, which we keep in since we feel they are still relevant to creative industries and in particular to our Arts and Humanities graduates. In reference to SIC codes (Creative Industries) we include 7420 (Architectural and engineering activities and related technical consultancy) as part of Architecture - given both NESTA and DCMS state part of this sector is relevant to creative industries; as the DCMS do we include 1700(Manufacture of textiles), 1800 (Manufacture of wearing apparel ) and 1900 (Manufacture of leather) despite NESTA (2008) suggesting we drop these as a reasonable number of the firms are in the design (namely fashion) business within our sample; we include 9250 - Library, archives, museums and other cultural activities, as these are likely to be relevant to Arts and Humanities students. Since only a small proportion (5\% as stated by the DCMS) of the codes 5240 (Other retail sale of new goods in specialised stores) and 5250 (Retail sale of second-hand goods in stores) represent creative industries we follow NESTA and ignore these codes and hence remove the category of Arts and Antiques. Following NESTA we exclude the 7480 (Other business activities not elsewhere classified) sector since it is difficult to identify the relevant creative industries, which only represent a small proportion (25\%), as well as excluding 9272 (other recreational activities) for the same reason.

${ }^{\mathrm{xv}}$ We included design and development engineers with architecture rather than with the category design, designer fashion, which the DCMS used, since we felt this was more closely linked with architecture than with other design occupations such as graphic designers, artists and designer fashion. Crafts were included with design and designer fashion due to small sizes and for the same reason Video, Film and Photography, were combined with Radio and Television. We also created a separate category for libraries, museums and cultural activities. 
${ }^{x v i}$ If we assume that full time individual's work a minimum of 30 hours for 52 weeks and using the minimum wage as of January 2006 which was $£ 4.25$ this equates to $£ 6630$ which we rounded down to $£ 6500$.

xvii The paper highlights the concentration of 'bohemian graduates' (i.e. graduates who obtained a degree in a 'bohemian' subject including creative arts, performing arts, design, mass communications, multi-media, software design and engineering, music recording and technology, architecture and landscape design) in London and the South East, where $37 \%$ of all bohemian graduates concentrate to study. It also considered the role played by London in terms of hosting the larger HEI in reference to bohemian graduates courses (the University of the Arts, London teaches $7 \%$ of the national student population in these courses) and in reference to specialisation (of the 21 HEIs in the UK whose percentage of students enrolled in Bohemian subjects is above 50\%, 10 are based in the Greater London area).

xviii UK HEIs can be classified into at least four different groups: 1. Russell group universities (20 research intensive universities who receive the majority of research grant and contract income); 2. Other 'old' universities; 3. New universities (established as part of the abolition of the binary divide in 1992); 4. Higher Education/Further education colleges. The Russell group universities, followed by the other old universities are generally considered to be more prestigious.

xix Elias and Purcell (2004a, p. 61) define the four categories as follows: traditional graduate occupations "the established professions, for which, historically, the normal route has been via undergraduate degree programme"; modern graduate occupations: "newer professions, particularly in management, IT and creative vocational areas, which"; new graduate occupations: "areas of employment, many in new or expanding occupations, where the route into the professional area has recently changed"; niche graduate occupations "occupations where the majority of incumbents are not graduates, but within which there are stable and growing specialist niches which require higher education skills" 